\title{
THE FIDUCIARY RELATIONSHIP BETWEEN A COMPANY AND ITS DIRECTORS
}

\author{
Lindi Coetzee
}

BJuris LLB LLM

Senior Lecturer of Mercantile Law

Nelson Mandela Metropolitan University

Port Elizabeth

Admitted Advocate of the High Court

Jan-Louis van Tonder*

LLB LLM

Attorney and Conveyancer of the

High Court of South Africa

\section{SUMMARY}

The fiduciary relationship that exists between a company and its directors is a universal concept. Section 5(2) of the Companies Act 71 of 2008 provides that, to the extent appropriate, a court interpreting or applying the provisions of the 2008 Act may consider foreign company law. This article examines the meaning of the word "fiduciary", when a fiduciary relationship comes into existence, the characteristics of a fiduciary relationship, the meaning of the term "director", different "types" of directors and discusses to whom the duties are owed. The nature of the fiduciary relationship in Australia and the State of Delaware in the United States of America is briefly compared with that of South Africa to identify similarities and differences. The research proposes a set of characteristics that can be considered when deciding whether a fiduciary relationship exists. The article does not propose that the set of characteristics identified must constitute a numerus clausus.

1

INTRODUCTION

In SEC v Chenery Corporation ${ }^{1}$ Frankfurter J held:

This article is based on Mr Van Tonder's LLM dissertation entitled: "Directors' Duties Under the Companies Act 71 of 2008". This dissertation was submitted in fulfilment of the requirements of the LLM degree in Mercantile Law at the Nelson Mandela Metropolitan University, Port Elizabeth.

318 US 80 (1943) 85-86. 
"To say that a man is a fiduciary only begins analysis; it gives direction to further inquiry. To whom is he a fiduciary? What obligations does he owe as a fiduciary?"'

A registered company is a juristic person ${ }^{3}$ that exists separately from its management and shareholders. ${ }^{4}$ A company cannot act on its own. ${ }^{5}$ It conducts its affairs through representatives. ${ }^{6}$ The company's business and affairs must be managed by or under the direction of its board. ${ }^{7}$ The board also has the authority to exercise all of the powers and perform any of the functions of the company. ${ }^{8}$ Owing to the statutory authority that directors have to manage the business and affairs of the company, it is important to identify the directors of a company and the scope of their role within the company. ${ }^{9}$ Directors are fiduciaries. ${ }^{10}$ They stand in an individual fiduciary relationship to the company of which they are directors. ${ }^{1}$

\section{MEANING OF "FIDUCIARY"}

The term "fiduciary" derives from the Latin term fiduciaries. ${ }^{12}$ Fiducia means "trust" and fidere means "to trust". ${ }^{13}$ According to Black's Law Dictionary ${ }^{14}$ a

2 SEC $v$ Chenery Corporation supra 85-86. See further, amongst others: Bishop and Prentice "Some Legal and Economic Aspects of Fiduciary Remuneration" 198346 MLR 289; Austin "Commerce and Equity - Fiduciary Duty and Constructive Trust" 19866 Oxford JLS 444; Miller "Justifying Fiduciary Duties" 201358 McGill LJ 1; Frankel "Fiduciary Law" 198371 California $L R$ 795; Smith "The Critical Resource Theory of Fiduciary Duty" 200255 Vanderbilt LR 1399; DeMott "Beyond Metaphor: An Analysis of Fiduciary Obligation" 1988 Duke LJ 879; DeMott "Disloyal Agents" 2006-2007 58 Alabama LR 1049; Gautreau "Demystifying the Fiduciary Mystique 198968 Can Bar Rev 1; Alces "Debunking the Corporate Fiduciary Myth" 200935 The Journal of Corporation Law 240; Cooter and Freedman "The Fiduciary Relationship: Its Economic Character and Legal Consequences" 199166 New York University LR 1045; Easterbrook and Fischel "Contract and Fiduciary Duty" 199336 Journal of Law and Economics 425; DeMott "Breach of Fiduciary Duty: On Justifiable Expectations of Loyalty and their Consequences" 200648 Arizona LR 1; Butler and Ribstein "Opting out of Fiduciary Duties: A Response to the Anti-Contractarians" 1990 65 Wash L Rev 1; Sitkoff "The Economic Structure of Fiduciary Law" 201191 Boston University LR 1039; Flannigan "The Economics of Fiduciary Accountability" 200731 Del J Corp L 393; Frankel "Fiduciary Duties and Default Rules" 199574 Or L Rev 1209; Sealy "Fiduciary Relationships" 1962 Cambridge LJ 69; and Shepherd "Towards a Unified Concept of Fiduciary Relationships" 198197 LQ Rev 51.

See s 19(1) of the 2008 Act.

Kennedy-Good and Coetzee "The Business Judgment Rule (Part 1) 200627 Obiter 6263.

Ibid; and Cassim, Cassim, Cassim, Jooste, Shev and Yeats Contemporary Company Law 2ed (2012) 187.

6 Kennedy-Good and Coetzee 2006 Obiter 63; eg, directors and officers; and Cassim et al Contemporary Company Law 187.

S 66(1) of the 2008 Act.

8 Except to the extent that this Act or the company's Memorandum of Incorporation provides otherwise - s 66(1) of the 2008 Act.

9 Cassim et al Contemporary Company Law 403.

10 Cassim et al Contemporary Company Law 509.

11 Blackman, Jooste and Everingham Commentary on the Companies Act (2002 loose-leaf) 837.

12 Oxford Dictionaries (undated) http://www.oxfordictionaries.com/definition/English/fidu ciary?q=fiduciary (accessed 2013-08-27).

13 Ibid. 
fiduciary is one who owes to another the duties of good faith, trust, confidence and candour and is required to exercise a high standard of care in managing another's money or property. Black's Law Dictionary ${ }^{15}$ also indicates that a person in a position of trust with fiduciary duties is expected to act primarily for the benefit of the person/entity that the fiduciary duties are owed to. A person in a fiduciary position exercises discretion over the affairs of another. ${ }^{16} \mathrm{~A}$ fiduciary is capable of asserting vulnerability of one person unto another and trust and reliance are placed in the other.

The meaning of the word fiduciary is based on the concepts of honesty, good faith, confidence, reliance and utmost trust. ${ }^{18}$ These concepts are centralized around the notion of loyalty. ${ }^{19}$

\section{THE EXISTENCE OF A FIDUCIARY RELATIONSHIP}

Courts are often required to determine whether fiduciary duties apply to a given relationship, but have not been able to articulate a clear standard for making this determination. ${ }^{20}$ Certain relationships have come to be clearly recognized as encompassing fiduciary duties while other relationships have not. $^{21}$ The concept of a fiduciary relationship is universal and may be found in different categories of relationships, for example trustee/beneficiary relationships, director/company relationships, agent/principal relationships and attorney/client relationships. ${ }^{22}$ The list of fiduciary relationships is not closed. ${ }^{23}$

In Robinson v Randfontein Estates Gold Mining Co Ltd ${ }^{24}$ the court held that a fiduciary relationship exists where one man stands to another in a

14 Garner (ed in chief) Black's Law Dictionary 8ed (2004) 702.

15 Campell Black's Law Dictionary http://thelawdictionary.org/fiduciary/ 2nd edition online Legal Dictionary (accessed 2014-11-17).

16 Hospital Products Ltd v United States Surgical Corporation [1984] HCA 64 par 68; and Volvo (Southern Africa) (Pty) Ltd v Yssel [2009] 4 All SA 497 (SCA) par 17; and see also ASIC v Citigroup Global Markets Australia Pty Limited [2007] FCA 963 [274].

17 Volvo (Southern Africa) (Pty) Ltd v Yssel supra par 17; and see also ASIC v Citigroup Global Markets Australia Pty Limited supra par 274.

18 Ibid.

19 McLennan "Directors' Fiduciary Duties and the 2008 Companies Bill" 20091 TSAR 184 185; and Bristol and West Building Society v Mothew [1996] 4 All ER (CA) 698711.

Smith 200255 Vanderbilt LR 1411-1412.

21 Volvo (Southern Africa) (Pty) Ltd $v$ Yssel supra par 16.

22 Ibid.

23 Ibid, "[w]hile certain relationships have come to be clearly recogni[s]ed as encompassing fiduciary duties there is no close list of such relationships"; According to Nugent JA (Streicher ADP, Jafta, Maya JJA and Hurt AJA concurring) in Volvo (Southern Africa) (Pty) Ltd $v$ Yssel supra par 17 "such references do not seem to me to advance materially what was stated in Randfontein Estates and do little more than to identify factors that were considered to be relevant to the enquiry in the particular case"; and in ASIC v Citigroup Global Markets Australia Pty Limited supra par 274, Jacobson J, quoting Professor Finn in the "The Fiduciary Principle" in Youdan (ed) Equity, Fiduciaries and Trusts (1989) 46-47, submits that "[a]scendancy, influence, vulnerability, trust, confidence or dependence doubtless will be of importance in making this out, but they will be important only to the extent that they evidence a relationship suggesting that entitlement".

241921 AD 168. 
position of confidence involving a duty to protect the interests of that other. ${ }^{25}$ Whether a particular relationship should be regarded in law as being one of trust will depend on the facts of the particular case. ${ }^{26}$

Courts have identified characteristics that impart fiduciary qualities to a particular relationship. ${ }^{27}$ Factors to be taken into account to determine whether a fiduciary relationship has been created include discretion, influence, vulnerability and trust. ${ }^{28}$ However, such references do little more than to identify factors that may be considered to be relevant to the enquiry in the particular case. ${ }^{29}$

In Bristol and West Building Society $v$ Mothew $^{30}$ Millet LJ held that a fiduciary is someone who undertakes to act for or on behalf of another in circumstances that give rise to a relationship of trust and confidence between the parties. However, a mutual understanding or undertaking is not a prerequisite for the existence of a fiduciary relationship. ${ }^{31}$ They are evidential factors considered relevant when required to make a determination in a particular enquiry. ${ }^{32}$ Contractual obligations that contain elements of trust may in a particular relationship help indicate whether a relationship is a relationship of trust. ${ }^{33}$ However, a legally recognized relationship is also not a prerequisite for the existence of a relationship of trust. $^{34}$

Apart from the evidential factors, ${ }^{35}$ relationships in which a fiduciary duty has been imposed are marked by three elements, ${ }^{36}$ namely:

(i) scope for the exercise of some discretion or power;

(ii) that power or discretion can be used unilaterally so as to effect the beneficiary's legal or practical interests; and

(iii) a peculiar vulnerability to the exercise of that discretion or power. ${ }^{37}$

These factors are indicative of the existence of a fiduciary relationship but are not the only factors that can be considered to establish whether a

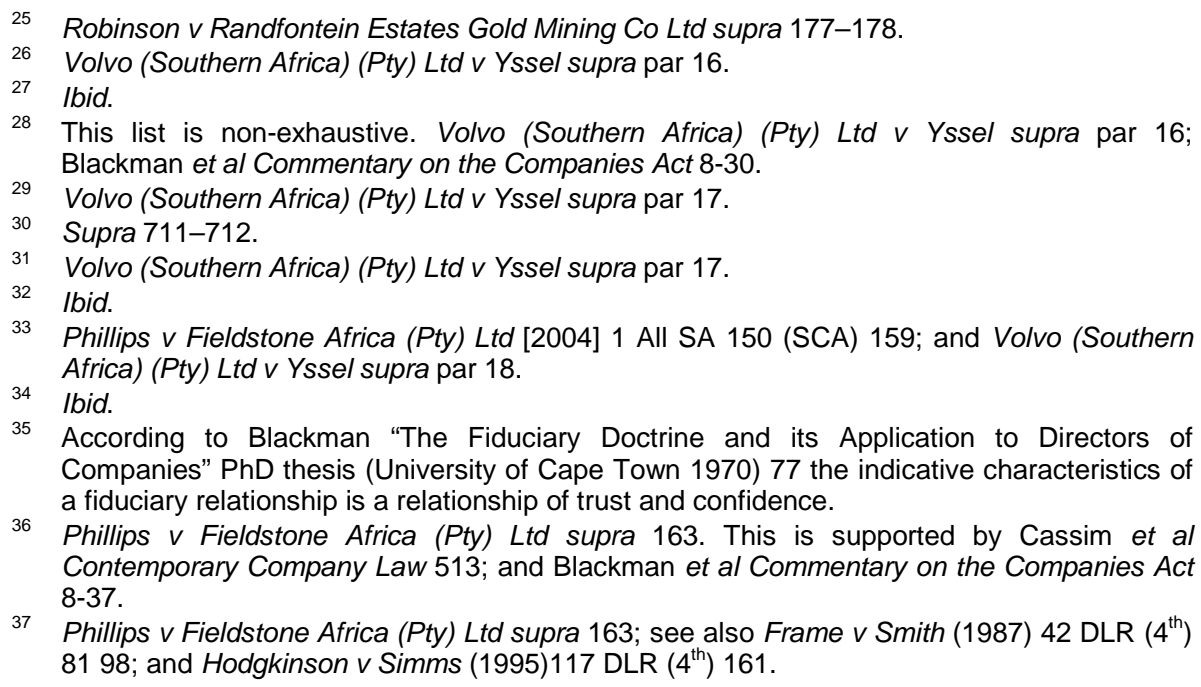

36 Phillips $v$ Fieldstone Africa (Pty) Ltd supra 163. This is supported by Cassim et al Contemporary Company Law 513; and Blackman et al Commentary on the Companies Act 8-37.

37 Phillips $v$ Fieldstone Africa (Pty) Ltd supra 163; see also Frame $v$ Smith (1987) 42 DLR $\left(4^{\text {th }}\right)$ 81 98; and Hodgkinson $v$ Simms (1995) 117 DLR $\left(4^{\text {th }}\right) 161$. 
fiduciary relationship exists. ${ }^{38}$ Whether a fiduciary relationship exists will depend upon the circumstances of each case. ${ }^{39}$ The three elements appear to be the absolute minimum that is required for the existence of a fiduciary relationship. 40

The director's fiduciary relationship to the company arises from the nature of his position in relation to the company and the company's position in relation to him. ${ }^{41}$ It arises from the purpose with which directors are entrusted with powers to manage the business and affairs of the company, to relinquish their own self-interest and act solely on behalf of and in the interests of the company.

The court ${ }^{43}$ in Phillips $v$ Fieldstone Africa (Pty) Ltd $^{44}$ recommended that the facts and circumstances in each case be carefully examined to determine whether the director is in a fiduciary relationship. ${ }^{45}$

38 Phillips v Fieldstone Africa (Pty) Ltd supra 163. See also Blackman et al Commentary on the Companies Act 8-37.

39 Robinson v Randfontein Estates Gold Mining Co Ltd supra 180.

40 Based on the principles of the Phillips judgment, for purposes of proper pleadings Harms Amlers Precedents of Pleadings (2009) 1 recognizes at least three characteristics of a fiduciary relationship, which are: (a) scope for the exercise of some discretion or power; (b) a power or discretion that can be used unilaterally to affect the beneficiary's legal or practical interests; and (b) a peculiar vulnerability to the exercise of that discretion or power.

41 Robinson v Randfontein Estates Gold Mining Co Ltd supra 177-178; Sibex Construction (SA) (Pty) Ltd v Injectaseal CC 1988 (2) SA 54 (T) 65; Cyberscene Ltd v i-Kiosk Internet and Information 2000 (1) SA 806 (C) 820; Hospital Products Ltd v United States Surgical Corporation supra par 69-70; and Blackman et al Commentary on the Companies Act 8-38.

42 S 66(1) of the 2008 Act; s 76 of the 2008 Act; and African Claim \& Land Co Ltd v W J Langermann 1905 TS 494504 Innes CJ submitted that "[a]n ordinary director is a mandatory, entrusted, in conjunction with his co-directors, with the management of the company's affairs; bound to exercise the utmost good faith in transacting with them; to give the company the benefit of his judgment and experience; and to render that amount of diligence which an ordinary prudent and careful man would display under the circumstances".

43 Phillips v Fieldstone Africa (Pty) Ltd supra 161.

44 Boardman v Phipps [1966] 3 All ER 721 758; and Harms Amlers Precedents of Pleadings 70 also recognizes the essential allegations to establish a breach of a fiduciary duty from these judgments, namely: (a) the plaintiff must allege facts from which the existence of such a duty can be deduced; (b) make the necessary allegations concerning the particular duties imposed by the fiduciary duty; (c) plead facts concerning the breach of the duty from which accountability arises; and (d) identify the scope of the duty which is determined by the scope of accountability in that the agent is accountable for profits made within the scope and ambit of his duty.

45 In Volvo (Southern Africa) (Pty) Ltd v Yssel supra par 17 the court held "[w]hat is called for is an assessment, upon a consideration of all the facts, of whether reliance by one party upon the other was justified in the circumstances" and referring to the case of, eg, the relationship between principal and agent, of a guardian to a ward, director to a company or a solicitor to a client. See also Hospital Products Ltd v United States Surgical Corporation supra par 69 where Gibbs CJ pointed out "[i] doubt if it is fruitful to attempt to make a general statement of the circumstances in which a fiduciary relationship will be found to exist. Fiduciary relations are of different types, carrying different obligations ... and a test which might seem appropriate to determine whether a fiduciary relationship existed for one purpose might be quite inappropriate for another purpose". If a fiduciary relationship is found to exist between a director and his company it falls in the category of a commercial fiduciary relationship, see Havenga "Breach of Director's Fiduciary Duties: Liability on What Basis?" 19968 SA Merc LJ 366. 
In Phillips $v$ Fieldstone Africa (Pty) $L t d^{46}$ the court was required to consider the liability of an employee to account to his employer for secret profits made by the employee out of an opportunity which flowed from the course of his employment. The court had to decide whether the appellant, as an employee, was subject to a fiduciary duty.

The court found that the existence of a contract does not necessarily preclude the existence of fiduciary duties between parties. ${ }^{48}$ The existence of a fiduciary duty could be implied from the contract of employment although it is not a prerequisite for the existence of a fiduciary relationship. ${ }^{49}$ The court held that "[t]he existence of such a [fiduciary] duty and its nature and extent are questions of fact to be adduced from a thorough consideration of the substance of the relationship and any relevant circumstances which affect the operation of that relationship". ${ }^{50}$ The court held that the emphasis in the particulars of claim on the representative nature of the appellant's status and his duty to have accounted for the profits acquired by him in that capacity indicated that the appellant stood in a position of confidence and good faith which he was obliged to protect towards the respondents. ${ }^{51}$

\section{DUTIES OWED WHERE A FIDUCIARY DUTY IS FOUND TO EXIST}

In Phillips $v$ Fieldstone Africa (Pty) Ltd $^{52}$ the court found that once it was established that there was a fiduciary relationship, that relationship had to be examined to identify the specific duties that were imposed on the director and the ambit of the duties. ${ }^{53}$ The establishment of a fiduciary relationship

\footnotetext{
Supra.

Phillips v Fieldstone Africa (Pty) Ltd supra 159.

Ibid.

Ibid.

50 Ibid; Bellairs v Hodnett 1978 (1) SA 1109 (A) 1130; and it is not necessary to the define the fiduciary duty - Harms Amlers Precedents of Pleadings 70.

51 Phillips $v$ Fieldstone Africa (Pty) Ltd supra 159. According to Heher JA the principles presented under the Phillips judgments are consistent with the doctrine enunciated in the Robinson judgment and are "necessary for its effective operation" Phillips $v$ Fieldstone Africa (Pty) Ltd supra 162.

52 Harms Amlers Precedents of Pleadings 70 also recognizes the essential allegations to establish a breach of a fiduciary duty from these judgments, namely: (a) the plaintiff must allege facts from which the existence of such a duty can be deduced; (b) make the necessary allegations concerning the particular duties imposed by the fiduciary duty; (c) plead facts concerning the breach of the duty from which accountability arises; and (d) identify the scope of the duty which is determined by the scope of accountability in that the agent is accountable for profits made within the scope and ambit of his duty.

53 According to Harms Amlers Precedents of Pleadings 70 "in other words, the scope and ambit of the duties imposed on the defendant ... A fiduciary relationship prevents an agent from entering into any transaction that would cause his or her interests to clash with his or her duty. For instance, an agent employed to buy cannot sell his or her own property; an agent employed to sell cannot buy his or her own property. In addition the agent cannot make any profit from his or her agency other than the agreed remuneration. The duty extends not only to actual conflicts of interests but also to conflicts that are in a real sense possible".
} 
places certain fundamental duties on a director. ${ }^{54}$ According to Pretorius ${ }^{55}$ "[t]he paramount duty of directors, individually and collectively, is to exercise their powers bona fide in the best interests of the company". The fiduciary relationship requires of the director to act in good faith in what he believes to be the best interests of the company and should avoid a conflict of interest. ${ }^{56}$ To ensure that the director does not breach this fundamental duty, the fiduciary relationship imposes a ring of prophylactic duties around him, ${ }^{57}$ which are all aimed at protecting the company to whom the duties are owed. ${ }^{58}$ According to Blackman ${ }^{59}$ directors may not:

(i) exceed their powers;

(ii) exercise their powers for an improper or collateral purpose;

(iii) fetter their discretion;

(iv) place themselves in a position in which their personal interests conflict, or may possibly conflict, with their duties to the company;

(v) deal with the company otherwise than openly and in good faith;

(vi) make a secret profit;

(vii) take certain corporate opportunities;

(viii) compete with the company; or

(ix) misuse confidential information.

These duties do not replace any other duties which directors may owe, nor do those other duties assume the character of the fiduciary duties. ${ }^{60}$ Directors may act in breach of a fiduciary duty and in breach of some other duty. ${ }^{61}$ The scope and extent of the fiduciary duty depends on the nature of the relationship between the parties, the tasks or functions assigned or assumed by the directors, the nature and scope of the tasks or functions, the nature and character of the company and the course of dealing actually pursued by the company. ${ }^{62}$

54 Blackman et al Commentary on the Companies Act 8-39.

55 Pretorius, Delport, Havenga and Vermaas Hahlo's South African Company Law Through the Cases (1999) 279.

56 Blackman et al Commentary on the Companies Act 8-34.

57 In Phillips v Fieldstone Africa (Pty) Ltd supra 160-161, the court appears to have regarded the duty to avoid a conflict of interests as the full extent of the fiduciary duties. According to Cassim and Larkin Annual Survey of South African Law (2004) 487516 on this reasoning, other duties, such as the duty to act in the best interests of the beneficiary, to act within one's powers, to use one's powers for the proper purpose, and to exercise an unfettered discretion, are not properly fiduciary duties, despite the fact that they are often listed as such. Blackman et al Commentary on the Companies Act 8-39.

58 Blackman et al Commentary on the Companies Act 8-34; and according to Pretorius et al Hahlo's South African Company Law Through the Cases 279.

59 Blackman et al Commentary on the Companies Act 8-39.

$60 \mathrm{Ibid}$. Eg, the director's duty of care, skill and diligence is not a fiduciary duty. Bristol and West Building Society v Mothew supra 710-711.

$61 \mathrm{Eg}$, the duty of care, skill and diligence, unlawful competition or be guilty of theft or fraud; and Blackman et al Commentary on the Companies Act 8-39.

62 See Robinson v Randfontein Estates Gold Mining Co Ltd supra 178-179; and Blackman et al Commentary on the Companies Act 8-40. 


\section{AUSTRALIA}

Owing to the commonwealth heritage shared by South Africa and Australia ${ }^{63}$ the countries share the following similar characteristics of the fiduciary relationship:

- Directors stand in a fiduciary relationship to the corporation that they serve ${ }^{64}$

- the relationship and classification of the office of "director" is sui generis; ${ }^{65}$

- the categories of persons involved in a fiduciary relationship have not been defined in express terms; ${ }^{66}$

- the fiduciary relationship is not deemed to be a closed list of categories; ${ }^{67}$

- the courts prefer a case-by-case approach, ${ }^{68}$ and

- the duties created are based on loyalty, good faith and an avoidance of conflict of interests. ${ }^{6}$

Generally, as to when a fiduciary relationship exists, in Hospital Products Ltd v United States Surgical Corporation ${ }^{70}$ Mason J submits that:

63 In Phillips v Fieldstone Africa (Pty) Ltd supra Heher JA stated that, regarding the principles which govern the actions of a person who occupies a position of trust (as applied in Robinson v Randfontein Estates Gold Mining Co Ltd supra 168, "[t]he principles so stated remain true, not only for this country, but also in many Commonwealth (and United States) jurisdictions".

64 Tomasic, Bottomley and McQueen Corporations Law in Australia (2002) 317; Butcher Directors' Duties: A New Millennium, A New Approach? Vol 7 (2000) 20; and Cassidy Concise Corporations Law 5ed (2006) 216.

65 Butcher Directors' Duties: A New Millennium, A New Approach? Vol 717.

66 Hospital Products Ltd $v$ United States Surgical Corporation supra par 67 Mason J stated that "[a]s the courts have declined to define the concept, preferring instead to develop the law in a case by case approach"; see also Breen v Williams (1996) 186 CLR 71 par 22; News Limited v Australian Rugby Football League Limited and New South Wales Rugby League Limited [1996] FCA 1256 par 312; Australian Securities and Investment Commission v Citigroup Global Markets Australia Pty Limited [2007] FCA 963 par 270-272; and Tomasic et al Corporations Law in Australia 318.

67 Hospital Products Ltd v United States Surgical Corporation supar par 67 per Mason J; Breen v Williams supra par 22; and Tomasic et al Corporations Law in Australia 319.

68 Hospital Products Ltd v United States Surgical Corporation supra par 30 per Gibbs CJ; Breen $v$ Williams supra par 22 per Gaudron and McHugh JJ; News Limited v Australian Rugby Football League Limited and New South Wales Rugby League Limited supra par 312; United Dominions Corporation Limited v Brian Proprietary Limited [1985] HCA 49; (1985) 157 CLR 1 7-8 per Gibbs CJ; Australian Securities and Investment Commission v Citigroup Global Markets Australia Pty Limited supra par 270; The Bell Group Ltd (In liq) v Westpac Banking Corporation (No 9) [2008] WASC 239 par 4550; John Alexander's Clubs Pty Ltd v White City Tennis Club Ltd [2010] HCA 19; and Westpac Banking Corporation v The Bell Group Ltd (In liq) (No 3) [2012] WASCA 157 par 836.

69 See ss 181-185 of the Corporations Act 2001.

70 Supra; see also Australian Securities and Investment Commission v Citigroup Global Markets Australia Pty Limited supra par 272; United Dominions Corporation Limited v Brian Proprietary Limited supra 7-8; News Limited v Australian Rugby Football League Limited and New South Wales Rugby League Limited supra par 312; and Breen v Williams supra par 22. 
"The critical feature of the fiduciary relationship is that the fiduciary undertakes or agrees to act for or on behalf of or in the interests of another person in the exercise of a power or discretion which will affect the interest of that other person in a legal or practical sense. ${ }^{11}$ The relationship between the parties is therefore one which gives the fiduciary a special opportunity to exercise the power or discretion to the detriment of that other person who is accorindingly vulnerable to abuse by the fiduciary of his position. ${ }^{2}$ The expressions 'for', 'on behalf of' and 'in the interests of' signify that the fiduciary acts in a 'representative' character in the exercise of his responsibility, to adopt an expression use by the Court of Appeal."

According to Mason $\mathrm{J}^{74}$ the fiduciary undertakes, or agrees to act for or on behalf of or in the interests of another person in the exercise of a power of discretion that will affect the interest of that other person in a legal or practical sense. The fiduciary relationship has the inherent danger that the power or discretion will be exercised to the detriment of that other person and that other person is accordingly vulnerable to abuse by the fiduciary of his position. This interpretation has been in acknowledged by Blackman ${ }^{75}$ and Cassim.

\section{6}

\section{DELAWARE}

The position in Delaware differs in two in two respects from what was discussed above. In Delaware corporations' directors stand in a fiduciary relationship with the corporation and its shareholders. ${ }^{77}$ Directors owe a duty

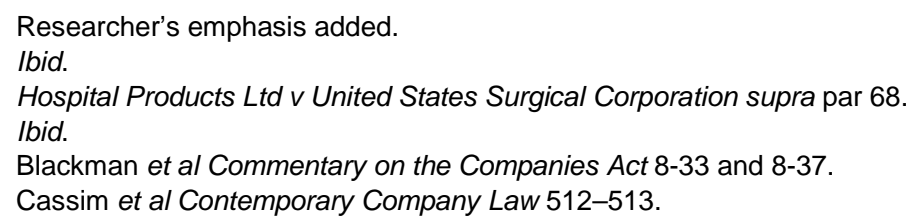
(Del. 1983); Unocal Corp v Mesa Petroleum Co 493 A.2d 946 (Del. 1985); Smith v Van Gorkom 488 A.2d 858 (Del. 1985); Revlon Inc v MacAndrews \& Forbes Holdings Inc 506 A.2d 173 (Del. 1986) 179; Ivanhoe Partners v Newmont Mining Corp 535 A.2d 1334 (Del. 1987); Grobow v Perot 539 A.2d 180 (Del. 1988); Mills Acquisition Co. v. Macmillan Inc, 559 A.2d 1171, 1174 (Del. 1988); Sternberg v O’Neil 550 A.2d 1105, 1124 (Del. 1988); Kaplan v Peat, Marwick, Mitchell \& Co, 540 A.2d 726, 729 (Del. 1988); Spiegel v Buntrock 571 A.2d 767, 773 (Del. 1990); Gilbert v El Paso Co 575 A.2d 1131, 1145-1147 (Del. 1990); Cede \& Co $v$ Technicolor Inc 634 A.2d 345 (Del. 1993) 361; Malone $v$ Brincat 722 A.2d 5, 10 (Del. 1998); Skeen v Jo-Ann Stores Inc 750 A.2d 1170, 1172 (Del. 2000); Seinfeld v Verizon Communications Inc 909 A.2d 117, 119 (Del. Supr. 2006); North American Catholic Educational Programming Foundation Inc v Gheewalla 930 A.2d 92, 99 (Del. 2007); Ebay Domestic Holdings Inc v Newmark 16 A.3d 1 (Del. Ch. 2010); see also Holland "Delaware Directors' Duties: The Focus on Loyalty" 200911 University of Pennsylvania Journal of Business Law 681; according to Gold "New Concept of Loyalty in Corporate Law" 200943 UC Davis LR 457494 "Directors hold a sui generis position in which they are given very broad discretion over how to manage the corporation"; and Strine Jr, Hamermesh, Balott and Gorris "Loyalty's Core Demand: The Defining Role of Good Faith in Corporation Law" 201098 The Georgetown LJ 629635. 
of loyalty and care to the corporation and its shareholders. ${ }^{78}$ Both duties are of equal and independent significance. ${ }^{79}$

In North American Catholic Educational Programming Foundation Inc $v$ Gheewalla ${ }^{80}$ the Delaware Supreme Court held the following:

"It is well established that the directors owe their fiduciary obligations to the corporation and its shareholders. While shareholders rely on directors acting as fiduciaries to protect their interests."

Thus, just as the board of directors owe the corporation a duty of care and loyalty they owe the same duties to the shareholders because they are considered to be fiduciaries of the shareholders. ${ }^{82}$

In Auriga Capital Corp v Gatz Properties $L L C^{83}$ Chancellor Strine held that "[u]nder Delaware law, "[a] fiduciary relationship is a situation where one person reposes special trust in and reliance on the judgment of another or where a special duty exists on the part of one person to protect the interests of another"' ${ }^{84}$ According to Chancellor Strine equity distinguishes fiduciary relationships from straightforward commercial transactions where there is no expectation that one party will act in the interests of the other. ${ }^{85}$ He further identified corporate directors as an analogous example of those Delaware law has determined owes a "special duty". Inc: ${ }^{87}$

The "special duty" Chancellor Strine referred to is described in Guth v Loft

"Corporate officers and directors are not permitted to use their position of trust and confidence to further their private interests. While technically not trustees, they stand in a fiduciary relation to the corporation and its stockholders. ${ }^{88} \mathrm{~A}$

78 Cede \& Co v Technicolor Inc supra 367.

79 In Cede \& Co v Technicolor Inc supra 367 the court held that: "The duty of the directors of a company to act on an informed basis, as that term has been defined by this Court numerous times, forms the duty of care element of the business judgment rule. Duty of care and duty of loyalty are the traditional hallmarks of a fiduciary who [endeavours] to act in the service of a corporation and its stockholders. Each of these duties is of equal and independent significance. In decisional law of this Court applying the rule ... this Court has consistently given equal weight to the rule's requirements of duty of care and duty of loyalty."

80 Supra.

81 North American Catholic Educational Programming Foundation Inc v Gheewalla supra 99 (researcher's emphasis added).

82 This leads to the another argument related to whether Delaware recognizes a shareholder primacy norm. Some argue Delaware does not and allow for directors to take into account stakeholder interests. See Stout "Why We Should Stop Teaching Dodge v Ford" 20083 Virginia L \& Bus Rev 16; Elhauge "Sacrificing Corporate Profits in the Public Interest" 2005 80 NYU LR 733; and Millon "Two Models of Corporate Social Responsibility" 201146 Wake Forest $L R 523$. The two cases usually relied on for an argument of shareholder primacy is the Dodge $v$ Ford Motor Co case and the Revlon Inc v MacAndrews \& Forbes Holdings Inc case.

83 C.A. 4390-CS (Del. Ch. Jan. 27, 2012).

84 Auriga Capital Corp v Gatz Properties LLC supra 17.

85 Auriga Capital Corp v Gatz Properties LLC supra 18.

86 Auriga Capital Corp v Gatz Properties LLC supra 17-18.

87 Supra.

88 Researcher's emphasis added. 
public policy, existing through the years, and derived from a profound knowledge of human characteristics and motives, has established a rule that demands of a corporate officer or director, peremptorily and inexorably, the most scrupulous observance of his duty, not only affirmatively to protect the interests of the corporation committed to his charge, but also to refrain from doing anything that would work injury to the corporation, or to deprive it of profit or advantage which his skill and ability might properly bring to it or to enable it to make in the reasonable and lawful exercise of its powers. ${ }^{89}$ The rule that requires an undivided and unselfish loyalty to the corporation demands that there shall be no conflict between duty and self-interest. ${ }^{90}$ The occasions for the determination of honesty, good faith and loyal conduct are many and varied, and no hard and fast rule can be formulated. The standard of loyalty is measured by no fixed scale."

This statement recognizes the fiduciary relationship, the fiduciary duty created thereby, which similarly betokens loyalty, good faith, trust and confidence, vulnerability and an avoidance of a conflict of interest. The court likewise recognized that the category of fiduciary relationships is not closed and that "no hard and fast rule" can be formulated to determine whether a fiduciary relationship exists. The fiduciary is required to act positively to protect the interests of the beneficiary.

\section{PERSONS WHO OWE A FIDUCIARY DUTY}

Directors, whether executive or non-executive, stand in a fiduciary relationship to their company. ${ }^{92}$ Under the common law a person becomes a fiduciary in relation to the company ${ }^{93}$, once the person accepts an appointment, ${ }^{94}$ or commences to act as a director (no formal appointment nor appointment invalid nor defective). ${ }^{95}$ Directors have been described as

\footnotetext{
Ibid.

Ibid.

Guth $v$ Loft Inc supra 510 (researcher's emphasis added).

African Claim and Land Co Ltd v W J Langermann supra 504; Robinson v Randfontein Estates Gold Mining Co Ltd supra 177-178; Regal (Hastings) Ltd v Gulliver [1942] 1 All ER (HL) 378 387-389; S v De Jager 1965 (2) SA 616 (A) 625; Industrial Development Consultants Ltd v Cooley [1972] 2 All ER 162 173-174; Atlas Organic Fertilizers (Pty) Ltd v Pikkewyn Ghwano (Pty) Ltd 19812 SA 173 (T) 198; Hospital Products Ltd v United States Surgical Corporation supra; Guiness plc v Saunders [1988] 2 All ER (CA) 940 945; Sibex Construction (SA) (Pty) Ltd v Injectaseal CC supra 65; Barlows Manufacturing Co Ltd v R N Barrie (Pty) Ltd 1990 (4) SA 608 (C) 610; Howard v Herrigel 1991 (2) SA 660 (A) 678; Cyberscene Ltd v i-Kiosk Internet and Information (Pty) Ltd supra 820; Phillips v Fieldstone Africa (Pty) Ltd supra; Volvo (Southern Africa) (Pty) Ltd v Yssel supra par 16; and Da Silva v C H Chemicals (Pty) Ltd [2009] 1 All SA 216 (SCA) 221.

93 Howard $v$ Herrigel supra 678.

94 See s 66(7); and see also Lindgren v L \& P Estates Ltd [1968] 1 All ER 917 922-923 held that a "director-elect" does not occupy a fiduciary position.

95 Pretorius et al Hahlo's South African Company Law Through the Cases 279; Blackman et al Commentary on the Companies Act 8-38; LAWSA 4(2) par 116; and Delport et al Henochsberg on the Companies Act 71 of 2008 (2012) 258(4).
} 
agents, trustees and managing partners. ${ }^{96}$ Directors are fiduciaries who owe fiduciary duties to the company of which they are the directors. ${ }^{97}$

\section{MEANING AND TYPES OF DIRECTORS}

\section{Meaning of the term "director"}

Section 1 of the Companies Act 71 of 2008 provides that a "director" means a member of the board of a company, as contemplated in section 66 , or an alternate director of a company and includes any person occupying the position of a director or alternate director, by whatever name designated. ${ }^{98}$ This definition includes all de jure directors 99 but not "pretended directors". ${ }^{100}$

The definition is similar to the definition in the 1973 Act. ${ }^{101}$ Apart from a director being defined as a member of the board of the company as contemplated in section 66, the definition provides that "a director is anyone who is a director, regardless of his title". ${ }^{102}$ The word "includes" in the definition indicates that the definition of a director is inclusive and not exhaustive ${ }^{103}$ and the meaning of "director" must be derived from the words of the 2008 Act as a whole. ${ }^{104}$ Any person who occupies the position of director is a director for the purposes of the 2008 Act, whether he is described as such or not. ${ }^{105}$ Accordingly, the definition is wide enough to

96 See generally Blackman et al Commentary on the Companies Act 8-9-11; Cassim et al Contemporary Company Law 412-414; Pretorius et al Hahlo's South African Company Law Through the Cases 270; and Delport et al Henochsberg on the Companies Act 71 of 2008 258(4).

97 Cassim et al Contemporary Company Law 509; directors are creatures of statute and occupy a unique position - Regal (Hastings) Ltd v Gulliver supra 387; and Cohen v Segal 1970 (3) SA 702 (W).

98 See Cassim et al Contemporary Company Law 404, breaking the phrase up into "includes" "occupying the position of a director" "by whatever name designated" "as contemplated in section 66". Henochsberg breaks the phrase up into "by whatever name designated" and "position of director" - see Delport et al Henochsberg on the Companies Act 71 of 200822 22(1).

99 A person validly and formally appointed to the position of a company director who has freely consented to that appointment - Re Hydrocam (Corby) Ltd [1994] BCC 161162.

100 Delport et al Henochsberg on the Companies Act 71 of 200822 describes "a pretended director" as a person who has neither been so appointed nor purportedly appointed, who is not within the deeming aforesaid and who simply arrogates to himself and exercises the powers of a director under the 2008 Act and the Memorandum of Incorporation is not, it is submitted, a director for purposes of the 2008 Act.

$101 \mathrm{~S} 1$ of the 1973 Act provided that in the 1973 Act, unless the context otherwise indicates, a director includes any person occupying the position of director or alternate director of a company, by whatever name designated.

102 Locke "Shadow Directors: Lessons from Abroad" 200214 SA Merc LJ 420; see also Re Mea Corporation Ltd [2007] BCC 288 par 82; Delport et al Henochsberg on the Companies Act 71 of 2008 22; and Cassim et al Contemporary Company Law 404.

103 Re Lo-Line Electric Motors Ltd [1988] 2 All ER 692 699. This means that the formalities are not crucial in attempting to identify those persons who are directors of a particular company - Cassim et al Contemporary Company Law 404.

104 Re Lo-Line Electric Motors Ltd supra 699.

105 Delport et al Henochsberg on the Companies Act 71 of 2008 22; and Cassim et al Contemporary Company Law 404 submits "it implies that for the purposes of the [2008] Act a person who is not formally appointed as a director of a company may nevertheless be 
recognize executive and non-executive directors, ${ }^{106}$ de facto directors, ${ }^{107}$ de jure directors and nominee directors. ${ }^{108}$ Other directors that are additionally recognized include temporary directors, ${ }^{109}$ shadow directors ${ }^{110}$ and puppet directors. ${ }^{11}$

The words "by whatever name designated" are "crucial" in determining who will qualify as directors. ${ }^{112}$ The words make it clear that certain persons may be regarded as directors even though they may be designated by a different name, deeming the title irrelevant.

Section 76(1) provides that in this section, "director" includes an alternate director, and a prescribed officer ${ }^{114}$ or a person who is a member of a committee of a board of a company, or of the audit committee of a company, irrespective of whether or not the person is also a member of the company's board. ${ }^{115}$ Section 76(1) includes a "director" as defined in section 1, an

deemed to be a director if he or she occupies the position of a director, whether with or without lawful authority".

106 See par 62 below.

107 See par 63 below.

108 Cassim et al Contemporary Company Law 410. Persons who, independently of the method of their appointment, but in relation to their office, are expected to act in accordance with some undertaking or arrangement which creates an obligation or mutual expectation of loyalty to some person or persons other than the company as a whole; and they may for instance, represent a major shareholder, a class of shareholders or debenture holders, a significant creditor or an employee group. Nominee directors, like any other director, must act in good faith in the best interest of the company and may not place their principal's interests before those of the company. Nominee directors have been considered under the duty to exercise an independent and unfettered discretion - Blackman et al Commentary on the Companies Act 8-13; and see also Fisheries Development Corporation of SA Ltd v Jorgensen; Fisheries Development Corporation of SA Ltd v AWJ Investments (Pty) Ltd [1980] 4 All SA 525 (W) 531, the court held "[h]e may in fact be representing the interests of the person who nominated him, and he may even be the servant or agent of that person, but, in carrying out his duties and functions as a director, he is in law obliged to serve the interests of the company to the exclusion of the interests of any such nominator".

$109 \mathrm{~S} 68(3)$ provides that, unless the Memorandum of Incorporation of a profit company provides otherwise, the board may appoint a person who satisfies the requirements for election as a director to fill any vacancy and serve as a director of the company on a temporary basis until the vacancy has been filled by election in terms of $s$ 68(2), and during that period any person so appointed has all of the powers, functions and duties, and is subject to all of the liabilities, of any other director of the company.

110 S 251(1) of the UK Companies Act 2006 provides that a shadow director is a person in accordance with whose directions or instructions the directors of the company are accustomed to act.

111 Cassim et al Contemporary Company Law 410. According to $S$ v Shaban 1965 (4) SA 646 (W) 652-653 a puppet director is a person placed on the board with the intention that he should blindly follow the instructions of his controller. The court held further that "[o]ur law does not know the complete puppet who pretends to take part in the management of a company whilst having no idea what it is to which he puts his signature. It is utterly foreign to the basic concepts of our law and the Courts will punish it as fraud" $-S v$ Shaban supra 652; and see also Sage Holdings Ltd v The Unisec Group Ltd 1982 (1) SA 337 (W) 354.

112 Delport et al Henochsberg on the Companies Act 71 of 2008 22; and Cassim et al Contemporary Company Law 404.

113 Cassim et al Contemporary Company Law 404.

114 S 76(1)(a).

$115 \mathrm{~S} 76(1)(\mathrm{b})$. The same applicability provision is contained in $\mathrm{S} 75(1), 77(1)$ and 78(1). S 78(1) additionally provides for a "former director". 
alternate director, as well as a prescribed officer, a person who is a member of a committee of a board of a company, or of the audit committee of a company, irrespective of whether or not the person is also a member of the company's board.

\section{Types of directors}

\section{Executive and non-executive directors}

An executive director is a director who is also an officer employed by the company. ${ }^{116} \mathrm{~A}$ non-executive director is any person who is a director of the company but who is neither an officer nor an employee of the company. ${ }^{117}$ An executive director participates in the day-to-day management of the company's affairs and is in full-time salaried employ of the company. ${ }^{118}$ This implies the existence of a service contract between the company and director. ${ }^{119}$

A non-executive director is a part-time director and is not involved in the day-to-day management and is not required to give continuous attention to the affairs of the company. ${ }^{120}$ His duties are of an intermittent nature to be performed at periodical board meetings and at any other meetings which may require his attention. ${ }^{121} \mathrm{He}$ is not, however, bound to attend all such meetings, though he ought to whenever he is reasonably able to do so. ${ }^{122}$

The 2008 Act does not distinguish between executive and non-executive directors. In Howard $v$ Herrigel ${ }^{123}$ the court held that once a person accepts an appointment as director, he becomes a fiduciary in relation to the company and is obliged to display the utmost good faith towards the company and his dealings on its behalf. ${ }^{124}$ Executive and non-executive directors have the same fiduciary duties in law. ${ }^{125}$

116 Blackman et al Commentary on the Companies Act 8-13.

117 Ibid.

118 Fisheries Development Corporation of SA Ltd $v$ Jorgensen; Fisheries Development Corporation of SA Ltd v AWJ Investments (Pty) Ltd supra 534; and Annexure 2.2 of the King Report on Governance for South Africa 2009 (hereinafter "the King III Report").

119 Blackman et al Commentary on the Companies Act 8-16-2 to 8-16-3.

120 Fisheries Development Corporation of SA Ltd $v$ Jorgensen; Fisheries Development Corporation of SA Ltd v AWJ Investments (Pty) Ltd supra 534; Re City Equitable Fire Insurance Co Ltd 1925 Ch 407 (CA) 428-429; Huckerby v Elliot [1970] 1 All ER 189 193194; and Annexure 2.3 of the King III Report.

121 Fisheries Development Corporation of SA Ltd $v$ Jorgensen; Fisheries Development Corporation of SA Ltd v AWJ Investments (Pty) Ltd supra 534.

122 Fisheries Development Corporation of SA Ltd $v$ Jorgensen; Fisheries Development Corporation of SA Ltd v AWJ Investments (Pty) Ltd supra 543; and Re City Equitable Fire Insurance Co Ltd 428-429.

123 Supra.

${ }^{124}$ Howard $v$ Herrigel supra 678.

125 Ibid. 


\section{Ex officio directors}

A company's Memorandum of Incorporation may provide for a person to be an ex officio director of the company as a consequence of that person's holding some other office, title, designation or similar status. ${ }^{126} \mathrm{~A}$ person who holds office or acts in the capacity of an ex officio director has all the powers and functions of any other director of the company, except to the extent that the company's Memorandum of Incorporation restricts the powers, functions or duties. ${ }^{127}$ An ex officio director has all the duties, and is subject to all of the liabilities, of any other director of the company.

\section{Alternate directors}

An alternate director is a person elected or appointed to serve, as the occasion requires, as a member of the board of a company in substitution for a particular elected or appointed director of that company. ${ }^{129}$ An alternate director may be only appointed if the Memorandum of Incorporation makes provision for a director to nominate an alternate director to substitute him when the occasion requires. ${ }^{130}$ An alternate director enjoys the powers of a director to the extent that his exercise of power does not derogate from his appointer's exercise of power. ${ }^{131}$ An alternate director is also required to discharge all his appointer's duties, powers and functions when acting in his stead. ${ }^{132}$ Alternate directors are in the same position as any other director. ${ }^{133}$ They do not serve as agents of their appointers while acting as alternate directors. ${ }^{134}$

\section{De facto directors and shadow directors}

In Re Hydrodam (Corby) Ltd ${ }^{135}$ the court held that a de facto director is a person who assumes to act as a director. ${ }^{136} \mathrm{He}$ holds himself out to be a

126 S 1 defines an ex officio director as a person who holds office as a director of a particular company solely as a consequence of that person holding some other office, title, designation or similar status specified in the company's Memorandum of Incorporation, $\mathrm{s}$ 66(4)(a)(ii).

$127 \mathrm{~S} 66(5)(\mathrm{b})(\mathrm{i})$.

128 S 66(5)(b)(ii). No person may serve as an ex officio director should he become ineligible or disqualified to be a director in terms of section 69 of the 2008 Act $-s$ 66(5)(a).

$129 \mathrm{~S} 1$.

130 S 66(4)(a)(iii).

131 Pretorius et al Hahlo's South African Company Law Through the Cases 334; and Cassim et al Contemporary Company Law 405.

132 See schedule 1, article 59 of Table A and article 60 of Table B of the 1973 Act.

133 Blackman et al Commentary on the Companies Act 8-12; and Cassim et al Contemporary Company Law 405.

${ }_{134}$ ASIC v Doyle [2001] WASC 187.

135 [1994] BCC 161.

136 Re Hydrodam (Corby) Ltd supra 163; and in R v Mall 1959 (4) SA 607 (N) 624 Caney J held that a de facto director means a person who has in fact been appointed as a director but in whose appointment there is some defect or irregularity. In such a case either the initial appointment was not legal or the original de jure director was rendered de facto when the defect occurred - Cassim et al Contemporary Company Law 408. 
director and claims and purports to be a director without having been so appointed, either validly or at all. ${ }^{137}$

The determination as to whether a particular person is a de facto director is a factual enquiry, the outcome of which will depend on all the relevant circumstances of the case. ${ }^{138}$ In order to determine whether a person is a de facto director of a company it must be proved that he undertook functions in relation to the company that could properly have been discharged only by a director. ${ }^{139}$ The de facto director must have participated in directing the affairs of the company on an equal footing with the de jure directors and not in a subordinate role. ${ }^{140}$ An exercise of "real influence" in the decisionmaking process of the company is necessary. ${ }^{141}$ To establish whether a particular person is a de facto director, it is necessary to establish whether the person assumed the status and functions of a company director, taking into consideration his/her actions rather than what he/she holds, claims or purports him-/herself to be. ${ }^{142}$ Influence of this nature in the governance structure of the company, coupled with the director assuming the role of office, imposes fiduciary duties on the director. ${ }^{143}$

A shadow director, on the other hand, refers to a person in accordance with whose directions or instructions the directors of the company are accustomed to act. ${ }^{144} \mathrm{~A}$ shadow director is not held out as a director by the

37 Re Hydrodam (Corby) Ltd supra 163.

138 Secretary of State for Trade and Industry v Tjolle [1998] BCC 282 290; and Re Kaytech International plc; Portier v Secretary of State for Trade and Industry [1999] BCC 390402.

139 Re Hydrodam (Corby) Ltd supra 163.

140 Gemma Ltd v Davies [2008] BCC 812 [40]; Secretary of State for Trade and Industry $v$ Hollier [2007] BCC 11 par 68-69 and 81; and Re Hydrodam (Corby) Ltd supra 163, the court held that it was not sufficient to show that he had been engaged in the management of the company's affairs or had undertaken tasks in relation to its business that could properly have been performed by a manager below board level.

141 Re Kaytech International plc; Portier v Secretary of State for Trade and Industry supra 402; Gemma Ltd v Davies supra par 40; Secretary of State for Trade and Industry v Hollier supra par 68-69 and 81.

142 A de facto director does not have to be held out by the company as a director - Gemma Ltd $\checkmark$ Davies supra par 40, but being held out as a director may support a finding that the person did in fact act as a director - Secretary of State for Trade and Industry $v$ Hollier supra par 66; Re Kaytech International plc; Portier $v$ Secretary of State for Trade and Industry supra 402; Re Hydrodam (Corby) Ltd supra 163; see also Idensohn "The Meaning of 'Prescribed Officers' Under the Companies Act 71 of 2008" 2012129 SALJ 717721 stating that "[t]he basic test therefore is whether the person in question 'assumed the status and functions of a company director', having regard to their actions rather than what they call themselves". This enquiry would include persons who claim to be and/or are held out as directors, as well as those who perform the functions of, and act on an equal footing with, de jure directors - Idensohn 2012129 SALJ 721; and Secretary of State for Trade and Industry v Deverell [2000] 2 All ER 365 374-376.

143 Holland $v$ Revenue and Customs Commissioners [2011] 1 All ER 430 445-446.

$144 \mathrm{~S} 251(1)$ of the UK Companies Act 2006 provides that a shadow director is a person in accordance with whose directions or instructions the directors of the company are accustomed to act. There are two express exclusions from the general definition. S 251(2) of the UK Companies Act 2006 provides that a person is not to be regarded as a shadow director by reason only that the directors act on advice given by him a professional capacity. S 251(3) of the UK Companies Act 2006 provides that a corporate entity is not to be regarded as a shadow director of any of its subsidiary companies for the purposes of certain of the Act's shadow director provisions by reason only that the directors of the subsidiary 
company. ${ }^{145}$ A shadow director exercises power from the shadows. ${ }^{146}$ The concept of a "shadow director" emerged to prevent the use of intermediaries acting as directors as a facade for the real exercise of power within the company. ${ }^{147}$

In Re Hydrodam (Corby) Ltd ${ }^{148}$ the court held that, to establish that a person is a shadow director of a company, it is necessary to allege and prove the following;

(i) Who are the directors of the company, whether de facto or de jure;

(ii) Did the defendant direct the appointed directors how to act in relation to the company or that he was one of the persons who did so;

(iii) Did the appointed directors act in accordance with such directions; and

(iv) Are the appointed directors accustomed to act in accordance with such person's directions.

Firstly, what is required is a board of directors claiming and purporting to act as such and secondly, a pattern of behaviour in which the board did not exercise any discretion or judgment of its own but acted in accordance with the directions of others. ${ }^{14}$

In Secretary of State for Trade and Industry $v$ Deverell ${ }^{150}$ the court held that a shadow director acts as a superior who instructs or directs the directors. It is not necessary to show that directors adopted a subservient role, surrendered their discretion or were under any compulsion to obey the directions or instructions, although a relationship of dominance and

are accustomed to act in accordance with its directions or instructions. S 1(2) of the 1973 Act explicitly excluded from the definition of a "director" a person who gives advice or instructions to the board in a professional capacity. The 2008 Act fails to adopt this section which allows for a situation where the definition of director may even be wider than intended. If the board is accustomed to act in accordance with the advice and instructions of a professional person given in his professional capacity, that person may well fall within the ambit of the definition of a "director" for purposes of s 76, 77 and 78 - Cassim et al Contemporary Company Law 510; see also McLennan "Directors' Duties and Misapplications of Company Funds" 198299 SALJ 394; Locke 200214 SA Merc LJ 420; Idensohn "The Regulation of Shadow Directors" 201022 SA Merc LJ 326; Idensohn 2012 129 SALJ 717; Delport et al Henochsberg on the Companies Act 71 of 200828.

145 Re Hydrodam (Corby) Ltd supra 163.

146 Ibid. See, however, Secretary of State for Trade and Industry v Deverell supra 376 indicating that "it is not necessary to the recognition of a shadow director that he should lurk in the shadows"; and in Kuwait Asia Bank EC v National Mutual Life Nominees Ltd [1991] AC 187 (PC) 223 the court held if only a minority of the company's directors was accustomed to act in accordance with a person's instructions or directions that person would not be deemed to be a shadow director.

147 Cassim et al Contemporary Company Law 410; and Idensohn 201022 SA Merc LJ 326 explains '[t]he concept of a 'shadow director' was introduced into English law almost a century ago for regulating people who exercise indirect influence or control by giving instructions or directions to a company's board of directors which the directors are accustomed to obey. Since then several other Commonwealth jurisdictions have also 148 Supra.

149 lbid.

150 Supra. 
subservience may be evidence of a shadow directorship. ${ }^{151}$ A shadow director must have influenced the majority of the directors who have become accustomed to act to his direction. ${ }^{152}$ Being accustomed to follow what a person says does not of itself make what is said, a direction or instruction. ${ }^{153}$ It must be proved that the board does what "the shadow" tells it and exercises no (or at least no substantial) independent judgment.

A shadow director does not always have to direct from or lurk in the shadows. ${ }^{155}$ The purpose is to identify those, other than professional advisers, with real influence in the corporate affairs of the company. ${ }^{156}$ It is not necessary for the directions or instructions to cover the whole of the company's corporate activities or affairs but must cover at least those matters essential to the corporate governance of the company, including control over its financial affairs. ${ }^{157}$ Whether any particular communication from the alleged shadow director, whether by words or conduct, should be classified as a direction or instruction must be determined objectively in the light of all the evidence. 158 The concepts of "direction" and "instruction" do not exclude the concept of "advice" because all three share the common feature of "guidance". ${ }^{159}$ It is not necessary to prove an understanding or expectation of either by the giver or the receiver. ${ }^{160}$ All that is required to be proved is the communication and its consequences. ${ }^{161}$ Evidence of a mutual understanding or expectation may be relevant but it cannot be conclusive. ${ }^{162}$ Non-professional advice could result in shadow directorship. ${ }^{163}$

\section{Prescribed officer}

"Prescribed officers" are defined to include persons, regardless of the designation of their office, who:

(a) exercise general executive control over and management of the whole, or a significant portion, of the business and activities of the company; or

(b) regularly participate to a material degree in the exercise of general executive control over and management of the whole, or a significant portion, of the business and activities of the company. ${ }^{164}$

\footnotetext{
151 Secretary of State for Trade and Industry v Deverell supra 376.

152 Ibid.

153 Secretary of State for Trade and Industry v Deverell supra 375.

154 Ibid.

155 Secretary of State for Trade and Industry $v$ Deverell supra 377.

156 Secretary of State for Trade and Industry v Deverell supra 375.

157 Ibid.

158 Secretary of State for Trade and Industry v Deverell supra 376.

159 Ibid.

160 Ibid.

161 lbid.

162 Ibid.

163 Ibid.

164 Regulation 38(1)(a) and (b) of the Companies Regulations, 2011 Published under GN R351 in GG 34239 of 26 April 2011.
} 
The title that is given to an office held by a person that meets the above definition or a function performed by such a person is irrelevant. ${ }^{165}$

The definition provided by the regulation is broad. ${ }^{166}$ It is submitted that a company secretary will qualify as a prescribed officer because the company officer is, in essence, the chief administrative officer of the company. ${ }^{1}$ Although the definition of "prescribed officer" does not expressly exclude de jure, de facto and alternate directors, there is room for the inclusion of a wide range of persons who participate in managing a company's business or activities. ${ }^{168}$ These persons may participate in or exercise their influence or control in various ways, to various degrees and they may do so either personally or directly, or indirectly through another person or persons. ${ }^{169}$

With regard to indirect participation, influence and control, one particularly problematic category of person is the "shadow director" ${ }^{170}$ Cassim ${ }^{171}$ and McLennan ${ }^{172}$ submit that shadow directors are recognized as directors because they occupy the position of a director which falls within the definition of a "director" as a type of de facto director. According to Idensohn ${ }^{173}$ this approach relies on a strained reading of the word "occupying" and will probably not be accepted by South African courts. ${ }^{174}$ Henochsberg ${ }^{175}$ and Idensohn ${ }^{176}$ submit that a shadow director could qualify as a prescribed officer. ${ }^{177}$ According to Idensohn ${ }^{178}$ taking into consideration the essential difference that a de facto director purports and claims to be a director, whereas the shadow director prefers to direct from the shadows, the "better conclusion" is that shadow directors are not "directors" and there is accordingly scope for them to be classified as "prescribed officers".

165 Regulation 38(2)(a) and (b) of the Companies Regulations, 2011.

166 Idensohn 2012129 SALJ 718; Cassim et al Contemporary Company Law 415; and Delport et al Henochsberg on the Companies Act 71 of 200828.

167 Delport et al Henochsberg on the Companies Act 71 of 2008 28; Havenga "Directors' Exploitation of Corporate Opportunities and the Companies Act 71 of 2008" 2013 TSAR 257 263 fn 44; and Cassim et al Contemporary Company Law 418 describing the company secretary as the chief administrative officer.

168 Idensohn 2012129 SALJ 721.

169 Ibid.

170 Idensohn 2012129 SALJ 721-722.

171 Cassim et al Contemporary Company Law 410 and 510.

172198299 SALJ 403.

1732012129 SALJ 724; and see also Idensohn 201022 SA Merc LJ 339

174 Idensohn 201022 SA Merc LJ 339 in fn 88 submits " $t$ t]o include a shadow director, the definition would have to be read as saying 'any person, directly or indirectly, occupying the position of a director' (emphasis supplied). Idensohn also points out that the argument fails to take account of the same kinds of factors that distinguish shadow directors from de facto directors. In support of her argument she refers to $S v$ Vandenberg 1979 (1) SA 208 (D), where it was held that there were clear indications in the 1973 Act the legislature never intended to recognize persons other than de jure and de facto directors as directors for any purpose. See Idensohn 201022 SA Merc LJ 339 fn 88; and Idensohn 2012129 SALJ 724 fn 53.

175 Delport et al Henochsberg on the Companies Act 71 of 200828.

1762012129 SALJ 724; and Idensohn 201022 SA Merc LJ 345.

177 See also Havenga 2013 TSAR 263 fn 44.

1782012129 SALJ 724; and Idensohn 201022 SA Merc LJ 326. 
Shadow directors may be regarded as prescribed officers due to the influence they have on major decisions of the company. ${ }^{179}$ The main constraint on this argument is whether indirect participation in the management and control of the company would be sufficient. ${ }^{180}$ If the $R e$ Hydrodam (Corby) $L t d^{181}$ factors are applied, namely, the requirement of a board of directors claiming and purporting to act as such and a pattern of behaviour in which the board did not exercise any discretion or judgment of its own but acted in accordance with the directions of others, the purpose is to identify those, other than professional advisers, with real influence in the corporate affairs of the company. ${ }^{12}$ The directions do not have to cover the whole of the company's corporate activities or affairs but must cover at least those matters essential to the corporate governance of the company including control over its financial affairs. ${ }^{183}$

\section{The business-rescue practitioner}

A business-rescue practitioner may also be regarded as a director, for purposes of section 76 during the business-rescue proceedings. ${ }^{184}$ Section $138(1)(d)$ provides that a person may be appointed as the business-rescue practitioner of a company only if the person would not be disqualified as a director of the company. ${ }^{185}$ Section $140(3)(b)$ provides that during a company's business-rescue proceedings, the practitioner has the responsibilities, duties and liabilities of a director. ${ }^{186}$

\section{ENTITY / PERSON TO WHOM FIDUCIARY DUTY IS OWED ${ }^{187}$}

On its formation a company is a legal entity that exists separately from its management and shareholders. ${ }^{188}$ As a general rule directors owe a fiduciary duty to the company as a whole and as a separate legal entity. ${ }^{189}$

179 Idensohn 2012129 SALJ 724; Idensohn 201022 SA Merc LJ 326; and Delport et al Henochsberg on the Companies Act 71 of 200828.

180 Idensohn 2012129 SALJ 724; Idensohn 201022 SA Merc LJ 335; and Delport et al Henochsberg on the Companies Act 71 of 200828.

181 Supra.

182 Secretary of State for Trade and Industry v Deverell supra 375.

183 Ibid.

$184 \mathrm{~S} 1$ is read with $\mathrm{s} 138(1)(\mathrm{d})$ and $140(3)(\mathrm{b})$ of the 2008 Act.

185 For purposes of $s$ 69(8) a prescribed officer is also deemed to be a director, s 69(8).

186 S 75-77.

187 This paragraph examines the company to whom the duties are owed and not other stakeholders' interests that the director must balance or take into consideration when acting in the interests of the company.

188 Cilliers, Benade, Henning, Du Plessis, Delport De Koker and Pretorius Corporate Law 3ed (2000) 139.

189 Blackman et al Commentary on the Companies Act 8-51; and Cilliers et al Corporate Law 139. 
Not to the company's individual shareholders, ${ }^{190}$ nor to its creditors while the company is a going concern, ${ }^{191}$ its employees, ${ }^{192}$ nor to its holding company, neither to its subsidiary company (at least where the subsidiary has an independent board of directors), nor, where the company is a member of a group of companies, to the group as a whole, does it owe fiduciary duty. ${ }^{193}$

As a general principle each company in a group of companies is regarded as a separate legal entity, ${ }_{195}$ unless the court pierces the corporate veil or it is done by the legislature. ${ }^{195}$ Under the common law a director of a holding company does not owe any fiduciary duties to its subsidiary. ${ }^{196}$ Similarly a director of a subsidiary only owes fiduciary duties to the subsidiary alone and does not owe fiduciary duties to the holding company. ${ }^{197}$ Thus, a director only owes his fiduciary duties to the company on whose board he serves and not to other companies even if they belong to the same group. ${ }^{198}$ However, due to the power exercisable by a holding company over a subsidiary, ${ }^{199}$ the 2008 Act attempts to alleviate the severity of the commonlaw principle ${ }^{200}$ by imposing a duty on directors not use the position of director nor any information obtained as directors to gain an advantage for the director nor for another person other than the company or a whollyowned subsidiary of the company nor to knowingly cause harm to the company or a subsidiary of the company.

The inclusion of a wholly-owned subsidiary ${ }^{202}$ and a subsidiary ${ }^{203}$ in the standards of directors' conduct provision represents an extension of the common-law principles. ${ }^{204}$ The duty extends the ambit beyond that of the company of which the person is a director. ${ }^{205}$ The structure of the wording indicates a positive duty ${ }^{206}$ to the wholly-owned subsidiary and a negative

190 Pretorius et al Hahlo's South African Company Law through the cases 278; Blackman et al Commentary on the Companies Act 8-51; and not even to a member who is a majority shareholder - Delport et al Henochsberg on the Companies Act 71 of 2008 296(3).

191 Pretorius et al Hahlo's South African Company Law through the cases 279; Blackman et al Commentary on the Companies Act 8-51; and Cassim et al Contemporary Company Law 516.

192 Cassim et al Contemporary Company Law 516.

193 Blackman et al Commentary on the Companies Act 8-51.

194 With its own rights and liabilities.

195 Cassim et al Contemporary Company Law 551.

196 Adams v Cape Industries plc [1991] 1 All ER (CA) 929.

197 Bell v Lever Bros Ltd [1931] All ER Rep 1; Scottish Co-operative Wholesale Society Ltd v Meyer [1958] 3 All ER (HL) 66 87-88; and Pergamon Press Ltd v Maxwell [1970] 2 All ER (Ch) 809 813-814.

198 Cilliers et al Corporate Law 141.

199 Ibid; and see also Robinson v Randfontein Estates Gold Mining Co Ltd supra 197-198.

200 Cassim et al Contemporary Company Law 551; and see also Robinson v Randfontein Estates Gold Mining Co Ltd supra 197-198.

$201 \mathrm{~S} 76(2)(\mathrm{a})$.

202 S 76(2)(a)(i).

203 S 76(2)(a)(ii).

204 Cassim et al Contemporary Company Law 551; Delport et al Henochsberg on the Companies Act 71 of 2008 290; and Delport The New Companies Act Manual (2011) 97.

205 Delport et al Henochsberg on the Companies Act 71 of 2008 290; and Delport The New Companies Act Manual 97.

206 It prescribes circumstances in which the director has a positive obligation to act. 
duty $^{207}$ to the subsidiary. ${ }^{208}$ When a subsidiary is used as an agent and/or when the directors of the holding company and the subsidiary company are the same, then the fiduciary duties will be extended, but it still remains independent duties towards two companies. ${ }^{209}$

\section{BREACH OF A FIDUCIARY DUTY AND ITS CONSEQUENCES}

The basis for directors' liability for breach of his fiduciary duties is based on the principle that a person standing in a fiduciary relationship to another commits a breach of trust if he acts for his own benefit or to the prejudice of another. ${ }^{210}$ The cause of action is neither delictual nor contractual but described as sui generis. ${ }^{211}$ The next question to determine is whether the director breached those duties by placing himself in a position where his personal interests conflict with that of the company. ${ }^{212}$ It is only at this stage that any question of accountability arises. ${ }^{213}$

In Phillips $v$ Fieldstone Africa (Pty) $L t d^{214}$ the court provided a summary of the present level of development of the law relating to a breach of a fiduciary duty and its consequences. ${ }^{215}$ The rule is a strict one and should be applied inexorably by the courts. ${ }^{216}$ It extends not only to actual conflicts of interest but also to those which are a real sensible possibility. ${ }^{217}$ Only the free consent of the principal after full disclosure by the fiduciary will suffice as a defence. $^{218}$ If the fiduciary acquires for himself the acquisition, it is deemed to have been acquired for the company. ${ }^{219}$ Once proof of a breach of a fiduciary duty is adduced it is of no relevance that: ${ }^{220}$

207 It prescribes circumstances in which the director has a negative obligation not to act.

208 Delport et al Henochsberg on the Companies Act 71 of 2008290.

209 Ibid; and Scottish Co-operative Wholesale Society Ltd v Meyer supra 87-88.

210 Robinson v Randfontein Estates Gold Mining Co Ltd supra 199 (per Innes CJ) 242 (per Solomon JA); Cohen v Segal supra 706; Du Plessis NO v Phelps 1995 (4) SA 154 (C) 170171: Beuthin and Luiz Beuthin's Basic Company Law 2ed (1992) 218; Pretorius et al Hahlo's South African Company Law Through the Cases 270-271; Cilliers et al Corporate Law 141 fn 24; Havenga 19968 SA Merc LJ 367; and Delport et al Henochsberg on the Companies Act 71 of 2008303.

211 Robinson v Randfontein Estates Gold Mining Co Ltd supra 199 (per Innes CJ) 242; Cohen v Segal supra 706; Du Plessis NO v Phelps supra 170-171; Beuthin and Luiz Beuthin's Basic Company Law 218; Pretorius et al Hahlo's South African Company Law Through the Cases 270-271; Cilliers et al Corporate Law 141 fn 24; Havenga 19968 SA Merc LJ 367; and Delport et al Henochsberg on the Companies Act 71 of 2008303.

212 Phillips v Fieldstone Africa (Pty) Ltd supra 162.

213 Ibid.

214 Supra 160-161.

215 See authorities listed there.

216 Phillips v Fieldstone Africa (Pty) Ltd supra 160.

217 Phillips v Fieldstone Africa (Pty) Ltd supra 161.

218 Ibid.

219 lbid.

220 See also Harms Amlers Precedents of Pleadings 70-71 the only defence available for a tainted transaction is the free consent of the principal following full disclosure by the agent. Because the acquisition is deemed to have been acquired for the company, once a breach of a fiduciary duty is established it is of no relevance that the company suffered no loss nor 
(i) the company suffered no loss nor damage;

(ii) the company could not itself have made use of the information nor opportunity, neither probably would not have done so;

(iii) the company, although it could have used the information or opportunity, refused it;

(iv) there is not privity between the principal and the party with whom the agent or servant is employed to contract business, and the money would not have gone into the principal's hands in the first instance;

(v) it was no part of the fiduciary's duty to obtain the benefit for the company; nor

(vi) the fiduciary acted honestly and reasonably. ${ }^{221}$

A breach may also occur beyond the term of the employment. ${ }^{222}$

Under the 2008 Act, directors may be held liable in accordance with the principles of the common law relating to breach of a fiduciary duty for any loss, damages or costs sustained by the company as a consequence of any breach by the director of a fiduciary duty. ${ }^{223}$ Under the common law the remedies of a company in the event of an actual threat and breach of the fiduciary duties include the following:

(i) a right to claim any profit or benefit ${ }^{224}$ arising from the breach of duty;

damage; could not itself have made use of the information or opportunity nor would not have done so in any event; refused to do so even if opportunity is at the company's disposal; no privity between the principal and the party with whom the agent or servant is employed to contract business and the money would not have gone into the principal's hands in the first instance; not part of the director's fiduciary duty to obtain the benefit for the company; nor the bona fides of the director.

221 Phillips v Fieldstone Africa (Pty) Ltd supra 161.

222 lbid.

223 See s 77(2) referring to s 76(2) and 76(3)(a) and (b).

224 An action for profits instituted by the company does not amount to an action for damages (Robinson v Randfontein Gold Mining Co Ltd supra 241-242; Symington v Pretoria-Oos Privaat Hospitaal Bedryfs (Pty) Ltd [2005] 4 All SA 403 (SCA) 411), neither is it an action based on contract, even in instances where an express or implied contract of mandate or agency gives rise to a fiduciary relationship, nor on delict. Robinson $v$ Randfontein Gold Mining Co Ltd supra 241-242; Cohen NO v Segal supra 706; Du Plessis NO v Phelps supra 170; Cyberscene Ltd v i-Kiosk Internet and Information (Pty) Ltd [1999] JOL 5198 (C) 24. The action is based on the fact that the director was an agent which relationship originates from his fiduciary relationship to the company, not a contract of agency. Robinson $v$ Randfontein Gold Mining Co Ltd supra 199 and 242. It is not an action based on delict because a breach of a fiduciary duty does not necessarily require fault to be involved, whether dolus or culpa. Robinson v Randfontein Gold Mining Co Ltd supra 199 and 241242; Cohen NO v Segal supra 706; and Du Plessis NO v Phelps supra 170-171. In Symington $v$ Pretoria-Oos Privaat Hospitaal Bedryfs (Pty) supra 411 in dealing with the nature of the claim against the director the court held that on a proper understanding of the plaintiff's claim it is not one for damages but a claim for disgorgement of profits received by the defendants as a result of allowing a diversion of a corporate opportunity away from the plaintiff, contrary to their fiduciary duties as directors of the plaintiff. The legal basis for the plaintiff's claim is therefore to be found in the principle that, where someone who owes a fiduciary duty to another, such as a director to his company, makes a profit for himself through a breach of his fiduciary duty, the law does not allow the director to retain the 
(ii) a right to set aside the transaction which amounts to breach of a duty;

(iii) the right to claim damages ${ }^{225}$ resulting from the breach; and

(iv) in appropriate circumstances, directors' may be restrained or prevented from the commission of a breach, or continuing breach, where such threat is imminent. ${ }^{226}$

\section{CONCLUSION}

The meaning of the word "fiduciary" is based on the concepts of honesty, good faith, confidence, reliance and utmost trust ${ }^{227}$ which are centralized around the notion of loyalty. ${ }^{228}$ It is no simple task to determine whether a fiduciary relationship exists. The concept of a fiduciary relationship is universal and may be found in different categories of relationships. The list of fiduciary relationships is not closed. ${ }^{229}$ Certain relationships are clearly recognized as encompassing fiduciary duties while other relationships are not. $^{230}$ Factors to be taken into account to determine whether a fiduciary relationship has been created include discretion, influence, vulnerability and trust. ${ }^{231}$ Whether a particular relationship should be regarded in law as being one of trust will depend on the facts of the particular case..$^{232}$

benefit that he acquired by such breach. Consequently, the company has an action, described as sui generis, to claim a disgorgement of that profit from him.

225 A claim for damages by the company for breach of a fiduciary duty is neither an action based on delict nor an action based on fault. Cohen NO $v$ Segal supra 706; Du Plessis NO $v$ Phelps supra 171; and Cyberscene Ltd $v$ i-Kiosk Internet and Information (Pty) Ltd supra 24. The company must be placed in the position it would have been as if there had been no breach of a duty. Atlas Organic Fertilizers (Pty) Ltd v Pikkewyn Ghwano (Pty) Ltd supra 197 and 200-201; and Du Plessis NO v Phelps supra 171. In Du Plessis NO v Phelps supra 171 , however, it was held that, although the action was not in delict and was not based on fault, the same principles of causation applied as those applicable in an action based on delict. It would be necessary for the company to satisfy the requirement of causation which proved the link between the damages and the breach of a fiduciary duty. If an action was instituted for damages, under the sui generis action for breach of a fiduciary duty, it had to be accepted that in such a claim the requirement of causation and the principles governing the requirement was no different from the principles applicable to an action based on delict. Du Plessis NO v Phelps supra 171; and Atlas Organic Fertilizers (Pty) Ltd v Pikkewyn Ghwano (Pty) Ltd supra 197. The same will apply if a breach of a fiduciary duty is alleged to have given rise to a delictual claim. Cohen NO v Segal supra 706; and Du Plessis NO v Phelps supra 171. The company will have an action for profits regardless of whether or not it has suffered a loss. Blackman et al Commentary on the Companies Act 8-45. If he also suffered a loss, it will also have an action or damages. Blackman et al Commentary on the Companies Act 8-45.

226 See generally Gihwala v Brown [2007] 20078 (C) 18, where Dlodlo J discussed the remedies for breach of a fiduciary duty.

227 Volvo (Southern Africa) (Pty) Ltd v Yssel supra par 17; and see also ASIC v Citigroup Global Markets Australia Pty Limited supra par 274.

228 McLennan 20091 TSAR 185; and Bristol and West Building Society v Mothew supra 711.

229 Volvo (Southern Africa) (Pty) Ltd v Yssel supra par 16-17; and ASIC v Citigroup Global Markets Australia Pty Limited supra par 274.

230 Volvo (Southern Africa) (Pty) Ltd $v$ Yssel supra par 16.

231 Ibid; and Blackman et al Commentary on the Companies Act 8-30.

232 Volvo (Southern Africa) (Pty) Ltd v Yssel supra par 16. 
The director's fiduciary relationship to the company arises from the nature of his position in relation to the company and the company's position in relation to him. ${ }^{233}$ It arises from the purpose for which directors are entrusted with their office and for which directors are entrusted with their powers to manage the business and affairs of the company, to relinquish their own self-interest and act solely on behalf of and in the interests of the company. ${ }^{234}$ A legally recognized relationship is not a prerequisite for the existence of a relationship of trust, ${ }^{235}$ nor is a mutual understanding or undertaking. ${ }^{236}$ They are evidential factors that are considered when it is required to make a determination in a particular enquiry.

Harms ${ }^{238}$ recognizes at least three characteristics of a fiduciary relationship, namely:

(i) scope for the exercise of some discretion or power;

(ii) a power or discretion that can be used unilaterally to affect the beneficiary's legal or practical interests; and

(iii) peculiar vulnerability to the exercise of that discretion or power.

The three characetristics are the minimum elements required for the existence of a fiduciary relationship. ${ }^{239}$

It is proposed that the following elements are indicative of the existence of a fiduciary relationship:

(i) a relationship of trust and confidence;

(ii) the fiduciary undertakes or agrees to act;

(iii) for, or on behalf of, or in the interests of another person (beneficiary);

(iv) given scope for the exercise of a power or discretion;

(v) that power or discretion can be used unilaterally to affect the interests of the other person in a legal or practical sense;

(vi) thus giving the fiduciary the special opportunity to exercise the power or discretion to the detriment of the other person; and

(vii) there is vulnerability of the other person to abuse by the fiduciary of his position.

\footnotetext{
233 Robinson v Randfontein Estates Gold Mining Co Ltd supra 177-178; Sibex Construction (SA) (Pty) Ltd v Injectaseal supra CC 65; Cyberscene Ltd v i-Kiosk Internet and Information supra 820; Hospital Products Ltd v United States Surgical Corporation supra par 69-70; and Blackman et al Commentary on the Companies Act 8-38.

${ }^{234}$ S 66(1) of the 2008 Act; s 76 of the 2008 Act; and African Claim \& Land Co Ltd v W J Langermann supra 504.

235 Phillips v Fieldstone Africa (Pty) Ltd supra 159; and Volvo (Southern Africa) (Pty) Ltd v Yssel supra par 18.

236 Volvo (Southern Africa) (Pty) Ltd v Yssel supra par 17.

237 Ibid.

238 Harms Amlers Precedents of Pleadings 1.

239 lbid.
} 
These elements are indicative of the existence of a fiduciary relationship but it is not proposed that they are the only elements that can be considered to establish whether a fiduciary relationship exists. ${ }^{240}$

Ultimately, whether a fiduciary relationship is established will depend upon the circumstances of each case. ${ }^{24}$

In all three jurisdictions no single test has been formulated to enable a court to identify whether a fiduciary relationship exists. Likewise, in all three jurisdictions the fiduciary relationship betokens loyalty, good faith, vulnerability, trust and confidence and an avoidance of a conflict of interest. Undivided and unselfish loyalty is required. The human nature of self-interest must be disregarded by the director in favour of the company. This requires a director to avoid placing himself in a position where there can be a conflict between his interest and duty to the company. The fiduciary relationship also requires a director to prevent injury to the company.

Once it is established that a fiduciary relationship exists, that relationship must be examined to identify the specific duties that are imposed on the director and the ambit of the duties. ${ }^{242}$ The existence of a fiduciary duty and its nature and extent are questions of fact to be adduced from a thorough consideration of the substance of the relationship and any relevant circumstances which affect the operation of that relationship. ${ }^{243}$ The fiduciary duty does not replace any other duties which directors may owe, nor do those other duties assume the character of a fiduciary duty. ${ }^{244}$ Directors may act in breach of a fiduciary duty and in breach of some other duty. ${ }^{245}$ The scope and extent of the fiduciary duty depends on the nature of the relationship between the parties, the tasks or functions assigned or assumed by the directors, the nature and scope of the tasks or functions, the nature and character of the company and the course of dealing actually pursued by the company. ${ }^{246}$

The paramount fiduciary duty of directors is to exercise their powers bona fide in the best interests of the company. ${ }^{247}$ To ensure that the director does not breach this fundamental duty, the fiduciary relationship imposes a ring of

240 Phillips v Fieldstone Africa (Pty) Ltd supra 163; and see also Blackman et al Commentary on the Companies Act 8-37.

241 Robinson v Randfontein Estates Gold Mining Co Ltd supra 180.

242 Harms Amlers Precedents of Pleadings 70.

243 Phillips v Fieldstone Africa (Pty) Ltd supra 159; Bellairs v Hodnett supra 1130; and Harms Amlers Precedents of Pleadings 70.

244 Blackman et al Commentary on the Companies Act 8-39; and Bristol and West Building Society $v$ Mothew supra 710-711.

$245 \mathrm{Eg}$, the duty of care, skill and diligence, unlawful competition or be guilty of theft or fraud. Blackman et al Commentary on the Companies Act 8-39.

246 See Robinson v Randfontein Estates Gold Mining Co Ltd supra 178-179; and Blackman et al Commentary on the Companies Act 8-40.

247 Pretorius et al Hahlo's South African Company Law Through the Cases 279. 
prophylactic duties around him, ${ }^{248}$ which are all aimed at protecting the company to whom the duties are owed. ${ }^{249}$

Under the common law a person becomes a fiduciary in relation to the company, ${ }^{250}$ once the person accepts an appointment, ${ }^{25}$ or commences to act as a director. ${ }^{252}$ Directors are fiduciaries who owe fiduciary duties to the company of which they are the directors. ${ }^{253}$

Section 76(1) includes a "director" as defined in section 1 of the 2008 Act, an alternate director, a prescribed officer, a person who is a member of a committee of a board of a company, or of the audit committee of a company, irrespective of whether or not the person is also a member of the company's board. Any person who occupies the position of director is a director for the purposes of the 2008 Act, whether he is described as such or not. ${ }^{254}$ The definition is wide enough to recognize executive and non-executive directors, de facto directors, de jure directors and nominee directors. ${ }^{255}$ Other directors that are additionally recognized include temporary directors, ${ }^{256}$ shadow directors ${ }^{257}$ and puppet directors. ${ }^{258} \mathrm{~A}$ business-rescue practitioner may also be regarded as a director, for purposes of section 76 during the business-rescue proceedings. ${ }^{25}$

The concept of de facto and shadow directors remains a contentious subject but it has become increasingly important to be able to distinguish between the two for purposes of bringing such a director within the definition of section 76 and thus establishing that such a director owes fiduciary duties to the company.

De facto directors will be subject to the fiduciary duties. ${ }^{260}$ With regard to shadow directors it remains unclear whether they will be regarded as directors under the definition of a director in terms of section 1 or as a prescribed officer under Regulation 38. According to Cassim ${ }^{261}$ and McLennan ${ }^{262}$ shadow directors are recognized as directors because they

248 In Phillips v Fieldstone Africa (Pty) Ltd supra 160-161.

249 Blackman et al Commentary on the Companies Act 8-34. According to Pretorius et al Hahlo's South African Company Law Through the Cases 279.

250 Howard v Herrigel supra 678.

251 See s 66(7); and see also Lindgren v L \& P Estates Ltd supra 922-923.

252 Pretorius et al Hahlo's South African Company Law Through the Cases 279; Blackman et al Commentary on the Companies Act 8-38; LAWSA 4(2) par [116]; and Delport et al Henochsberg on the Companies Act 71 of 2008 258(4).

253 Cassim et al Contemporary Company Law 509.

254 Delport et al Henochsberg on the Companies Act 71 of 2008 22; and Cassim et al Contemporary Company Law 404.

255 Cassim et al Contemporary Company Law 410; Blackman et al Commentary on the Companies Act 8-13; and see also Fisheries Development Corporation of SA Ltd v Jorgensen; Fisheries Development Corporation of SA Ltd v AWJ Investments (Pty) Ltd 531.

$256 \mathrm{~S} 68(3)$.

257 S 251(1) of the UK Companies Act 2006.

258 Cassim et al Contemporary Company Law 410.

$259 \mathrm{~S} 1$ is read with s $138(1)(\mathrm{d})$ and 140 (3)(b) of the 2008 Act.

260 S 1 read with s 76(1) of the 2008 Act.

261 Cassim et al Contemporary Company Law 410 and 510.

262198299 SALJ 403. 
occupy the position of a director which falls within the definition of a "director" as a type of de facto director. According to Idensohn ${ }^{263}$ this approach relies on a strained reading of the word "occupying" and will probably not be accepted by South African courts. ${ }^{264}$ Henochsberg ${ }^{265}$ and Idensohn 266 submit that a shadow director could qualify as a prescribed officer. ${ }^{267}$ According to Idensohn, ${ }^{268}$ taking into consideration the essential difference that a de facto director purports and claims to be a director whereas the shadow director prefers to direct from the shadows, the preferred view is that shadow directors are not "directors" and there is accordingly scope for them to be classified as "prescribed officers". Shadow directors may be regarded as prescribed officers due to the influence they have on major decisions of the company. ${ }^{269}$ The main constraint on this argument is whether indirect participation in the management and control of the company would be sufficient. ${ }^{27}$

The research found that if the Re Hydrodam (Corby) $L t d^{271}$ factors are applied, namely, the requirement of a board of directors claiming and purporting to act as such, and a pattern of behaviour in which the board did not exercise any discretion or judgment of its own, but acted in accordance with the directions of others, the purpose is to identify those, other than professional advisers, with real influence in the corporate affairs of the company. ${ }^{272}$ The directions do not have to cover the whole of the company's corporate activities or affairs but must cover at least those matters essential to the corporate governance of the company, including control over its financial affairs. ${ }^{273}$ Judicial determination is required in this regard. ${ }^{274}$

As a general rule directors owe a fiduciary duty to the company as a whole and as a separate legal entity. ${ }^{275}$ Each company in a group of companies is regarded as a separate legal entity ${ }_{27}^{276}$ unless the court pierces the corporate veil or it is done by the legislature. ${ }^{237}$ Under the common law a director owes his fiduciary duties only to the company on whose board he serves and not to other companies even if they belong to the same group. ${ }^{27}$

2632012129 SALJ 724; and see also Idensohn 201022 SA Merc LJ 339.

264 Idensohn 201022 SA Merc LJ 339 fn 88; S v Vandenberg supra; and Idensohn 2012129 SALJ 724 fn 53.

265 Delport et al Henochsberg on the Companies Act 71 of 200828.

266 Idensohn 2012129 SALJ 724; and Idensohn 201022 SA Merc LJ 345.

267 See also Havenga 2013 TSAR 263 fn 44.

2682012129 SALJ 724; and Idensohn 201022 SA Merc LJ 326.

269 Idensohn 2012129 SALJ 724; Idensohn 201022 SA Merc LJ 326; and Delport et al Henochsberg on the Companies Act 71 of 200828.

270 Idensohn 2012129 SALJ 724; Idensohn 201022 SA Merc LJ 335; and Delport et al Henochsberg on the Companies Act 71 of 200828.

271 Supra.

272 Secretary of State for Trade and Industry $v$ Deverell supra 375.

273 Secretary of State for Trade and Industry $v$ Deverell 375.

274 Ibid.

275 Blackman et al Commentary on the Companies Act 8-51; Cilliers et al Corporate Law 139.

276 With its own rights and liabilities.

277 Cassim et al Contemporary Company Law 551.

278 Cilliers et al Corporate Law 141. 
Owing to the power exercisable by a holding company over a subsidiary, ${ }^{279}$ the 2008 Act imposes a duty on directors not use the position of director nor any information obtained as directors to gain an advantage for the director nor for another person other than the company or a wholly-owned subsidiary of the company nor to knowingly cause harm to the company nor a subsidiary of the company. ${ }^{280}$ The inclusion of a wholly-owned subsidiary ${ }^{281}$ and a subsidiary ${ }^{282}$ in the standards of directors' conduct provision represents an extension of the common-law principles. ${ }^{283}$ The duty extends the ambit beyond that of the company of which the person is a director. ${ }^{284}$ When a subsidiary is used as an agent and/or when the directors of the holding company, and the subsidiary company are the same, then the fiduciary duties will be extended, but it still remains independent duties towards two companies. ${ }^{285}$

Directors may be held liable in accordance with the principles of the common law relating to breach of a fiduciary duty, for any loss, damages or costs sustained by the company as a consequence of any breach by the director of a fiduciary duty. ${ }^{286}$ Once proof of a breach of a fiduciary duty is adduced it is of no relevance that: ${ }^{287}$

(i) the company suffered no loss or damage;

(ii) the company could not itself have made use of the information nor opportunity, nor probably would not have done so;

(iii) the company, although it could have used the information or opportunity, refused it;

(iv) there is not privity between the principal and the party with whom the agent or servant is employed to contract business and the money would not have gone into the principal's hands in the first instance;

(v) it was no part of the fiduciary's duty to obtain the benefit for the company; nor

(vi) the fiduciary acted honestly and reasonably. ${ }^{288}$

The meaning of the word "fiduciary" is based on the concepts of honesty, good faith, confidence, reliance and utmost trust $^{289}$ which are centralized around the notion of loyalty.

\footnotetext{
279 Cilliers et al Corporate Law 141; See also Robinson v Randfontein Estates Gold Mining Co Ltd supra 197-198.

${ }^{280} \mathrm{~S} 76(2)(\mathrm{a})$

$281 \mathrm{~S} 76(2)(\mathrm{a})(\mathrm{i})$

${ }^{282} \mathrm{~S} 76(2)(\mathrm{a})(\mathrm{ii)}$.

283 Cassim et al Contemporary Company Law 551; Delport et al Henochsberg on the Companies Act 71 of 2008 290; Delport The New Companies Act Manual 97.

284 Delport et al Henochsberg on the Companies Act 71 of 2008 290; Delport The New Companies Act Manual 97.

285 Delport et al Henochsberg on the Companies Act 71 of 2008 290; Scottish Co-operative Wholesale Society Ltd v Meyer supra 87-88;

${ }^{286}$ See section 77(2) referring to section 76(2) and 76(3)(a) and (b).

287 See also Harms Amlers Precedents of Pleadings 70-71.

288 Phillips v Fieldstone Africa (Pty) Ltd supra 161.
} 
Whether a particular relationship should be regarded in law as being one of trust will depend on the facts of the particular case. ${ }^{291}$ Factors to be taken into account to determine whether a fiduciary relationship has been created include discretion, influence, vulnerability and trust. ${ }^{292} \mathrm{~A}$ legally recognized relationship is not a prerequisite for the existence of a relationship of trust ${ }^{293}$ nor is a mutual understanding or undertaking. ${ }^{294}$

The director's fiduciary relationship to the company arises from the nature of his position in relation to the company and the company's position in relation to him. ${ }^{295}$ It arises from the purpose for which directors are entrusted with their office and for which directors are entrusted with their powers to manage the business and affairs of the company, to relinquish their own self-interest and act solely on behalf of and in the interests of the company. ${ }^{296}$

The fiduciary duty does not replace any other duties which directors may owe nor do those other duties assume the character of a fiduciary duty. ${ }^{29}$ Directors may act in breach of a fiduciary duty and in breach of some other duty. ${ }^{298}$ The scope and extent of the fiduciary duty depends on the nature of the relationship between the parties, the tasks or functions assigned or assumed by the directors, the nature and scope of the tasks or functions, the nature and character of the company and the course of dealing actually pursued by the company. ${ }^{299}$

The paramount fiduciary duty of directors is to exercise their powers bona fide in the best interests of the company. ${ }^{300}$ To ensure that the director does not breach this fundamental duty, the fiduciary relationship imposes a ring of prophylactic duties around him, ${ }^{301}$ which are all aimed at protecting the company to whom the duties are owed. ${ }^{302}$

289 Volvo (Southern Africa) (Pty) Ltd v Yssel supra par 17; and see also ASIC v Citigroup Global Markets Australia Pty Limited supra par 274.

290 McLennan 20091 TSAR 185; and Bristol and West Building Society v Mothew supra 711.

291 Volvo (Southern Africa) (Pty) Ltd v Yssel supra par 16.

$292 \mathrm{Ibid}$; and Blackman et al Commentary on the Companies Act 8-30.

293 Phillips v Fieldstone Africa (Pty) Ltd supra 159; and Volvo (Southern Africa) (Pty) Ltd v Yssel supra par 18

294 Volvo (Southern Africa) (Pty) Ltd v Yssel supra par 17.

295 Robinson v Randfontein Estates Gold Mining Co Ltd supra 177-178; Sibex Construction (SA) (Pty) Ltd v Injectaseal CC supra 65; Cyberscene Ltd $v$ i-Kiosk Internet and Information 820; Hospital Products Ltd v United States Surgical Corporation supra par 69-70; and Blackman et al Commentary on the Companies Act 8-38.

296 S 66(1) of the 2008 Act; s 76 of the 2008 Act; and African Claim \& Land Co Ltd v W J Langermann supra 504.

297 Blackman et al Commentary on the Companies Act 8-39; and Bristol and West Building Society $v$ Mothew supra 710-711.

$298 \mathrm{Eg}$, the duty of care, skill and diligence, unlawful competition or be guilty of theft or fraud. Blackman et al Commentary on the Companies Act 8-39.

299 See Robinson v Randfontein Estates Gold Mining Co Ltd supra 178-179; and Blackman et al Commentary on the Companies Act 8-40.

300 Pretorius et al Hahlo's South African Company Law Through the Cases 279.

301 In Phillips v Fieldstone Africa (Pty) Ltd supra 160-161.

302 Blackman et al Commentary on the Companies Act 8-34. According to Pretorius et al Hahlo's South African Company Law Through the Cases 279. 
When a subsidiary is used as an agent and/or when the directors of the holding company and the subsidiary company are the same then the fiduciary duties will be extended, but it still remains independent duties towards two companies. ${ }^{303}$

Directors may be held liable in accordance with the principles of the common law relating to breach of a fiduciary duty, for any loss, damages or costs sustained by the company as a consequence of any breach by the director of a fiduciary duty. ${ }^{304}$

303 Delport et al Henochsberg on the Companies Act 71 of 2008 290; and Scottish Cooperative Wholesale Society Ltd v Meyer supra 87-88.

304 See s 77(2) referring to s 76(2) and 76(3)(a) and (b). 